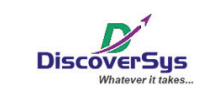

Published by DiscoverSys

\section{Barriers to Encourage Motivation in Relation to Work Performance of Nurses in Buleleng District Hospital}

\author{
Budiastri, ${ }^{1,4^{*}}$ Ayu Indrayathi, ${ }^{1,2}$ I Putu Ganda Wijaya ${ }^{1,3}$
}

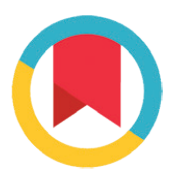

CrossMark

\section{ABSTRACT}

Background and purpose: Nurses at hospitals regularly receives criticism from the general public, negatively commenting on their lack of patient care, lack of professionalism and diminished quality of service. Survey findings on patient satisifaction at Buleleng Public Hospital from 2011 indicate that $2.03 \%$ of patients remained unsatisfied with staff workplace attitudes and $6.39 \%$ felt that nursing service overall was unsatisifactory. Preliminary interviews with ward nurses on 24 November 2012 exposed a number of issues: a lack of career support and development for nurses, including opportunities to expand their skills, and a lack of workplace satisifaction from patient supplementary income. Weakness regarding technical support and motivation from ward supervisors evidently also has an impact on nurses workplace motivation and therefore quality of service. This research investigates the influence of supervision, career development, supplementary income support, and administrational records on the workplace attitude of nursing staff.

Methods: Research was formulated using qualitative and phenomenology methods. Informants were purposively selected. Data was collected through in-depth interviews and administration documentation study and analysed using thematic analysis.

Results and conclusion: Findings indicated that little monitoring and evaluation of nurse workplace attitudes, a lack of support and motivational direction from supervisors, administrational documentation issues, minimun supplementary income support, as well as career development had a large impact on nurse quality of care. Most dominant variables included supervision, career development and supplementary income support.

\title{
Hambatan-hambatan dalam Pengembangan Motivasi Terkait Kinerja Perawat di RSUD Kabupaten Buleleng
}

\section{ABSTRAK}

Latar belakang dan tujuan: Masyarakat sering mengeluh atas kinerja perawat yang kurang bermutu, profesional atau empati dalam memberikan asuhan keperawatan. Analisis kepuasan pasien yang berkunjung ke RSUD Kabupaten Buleleng 2011 menunjukkan 2,03\% kinerja petugas tidak baik dan 6,39\% kualitas pelayanan kurang memuaskan. Wawancara perawat Instalasi Rawat Inap

PPublic Health Postgraduate Program Udayana University, ${ }^{2}$ Department of Public Health, Faculty of Medicine Udayana University, ${ }^{3}$ Bangli District Health Department,

${ }^{4}$ District Public Hospital of Buleleng

*Correspondence to: Budiastri, Public Health Postgraduate Program Udayana University, District Public Hospital of Buleleng

budiastriketut@yahoo.co.id
Metode: Rancangan penelitian adalah kualitatif dengan pendekatan fenomenologi. Informan adalah kepala ruangan dan perawat pelaksana yang dipilih secara purposive. Data dikumpulkan dengan wawancara mendalam dan studi dokumentasi penerapan standar asuhan keperawatan. Analisis data wawancara menggunakan thematic analysis.

Hasil dan simpulan: Supervisi keperawatan bersifat rutinitas, tanpa adanya monitoring dan evaluasi, serta tidak memberikan dorongan dan bimbingan kepada perawat. Selain itu pengembangan karir terkendala terbatasnya sumber daya manusia dan belum meratanya mendapatkan pelatihan, jasa pelayanan yang diterima oleh perawat tidak sesuai harapan atau tidak sesuai dengan tindakan yang telah mereka lakukan/berikan kepada klien. Penerapan dokumentasi asuhan keperawatan belum sesuai standar. 


\section{PENDAHULUAN}

Salah satu bentuk penilaian yang dilakukan di Rumah Sakit Umum Daerah (RSUD) Kabupaten Buleleng dalam mengetahui opini pengguna jasa adalah dengan melakukan survei kepuasan pasien meliputi kategori kinerja petugas secara umum dan kualitas pelayanan rumah sakit (RS) secara keseluruhan. Hasil analisis kepuasan pasien yang berkunjung ke RSUD Kabupaten Buleleng tahun 2011 menunjukkan sebanyak 3,98\% kinerja petugas secara umum kurang baik dan 2,03\% kinerja petugas secara umum tidak baik. Selain itu, sebanyak 6,39\% kualitas pelayanan kurang memuaskan dan 1,50\% kualitas pelayanan tidak memuaskan. ${ }^{1}$

Hasil wawancara awal kepada perawat yang dilakukan peneliti di RSUD Kabupaten Buleleng pada tanggal 24 November 2012, menemukan beberapa masalah diantaranya kesempatan untuk mengikuti pendidikan dan pelatihan yang belum merata, adanya jasa pelayanan yang tidak memuaskan, perawat mengatakan bahwa mereka bekerja hanya sebagai rutinitas saja. Selain itu, diakui tidak adanya pengawasan, dukungan dan motivasi dari pimpinan kepada perawat dalam melaksanakan asuhan keperawatan. Semua ini tentu saja akan menjadi hambatan-hambatan motivasi perawat dalam memberikan asuhan keperawatan yang profesional kepada klien yang selanjutnya akan berdampak terhadap kinerja perawat.

Motivasi kerja digambarkan sebagai hasil interaksi antara individu dan situasinya, setiap manusia mempunyai motivasi berbeda antara yang satu dengan yang lain dan dirumuskan sebagai perilaku yang ditujukan pada sasaran dan berkaitan dengan tingkat usaha yang dilakukan seseorang dalam mengejar sesuai tujuan. ${ }^{2}$ Seseorang yang tidak termotivasi hanya memberikan upaya minimum dalam hal bekerja. ${ }^{3}$ Masukan individual dan konteks pekerjaan merupakan dua faktor kunci yang mempengaruhi motivasi dan kedua faktor tersebut saling mempengaruhi. Kinerja merupakan implementasi dari Teori Keseimbangan, yang mengatakan bahwa seseorang akan menunjukkan prestasi yang optimal bila ia mendapatkan manfaat dan terdapat adanya rangsangan dalam pekerjaannya secara adil dan masuk akal. ${ }^{5}$ Faktor-faktor yang mempengaruhi motivasi: (1) adanya instrumen kinerja untuk promosi dan peningkatan penghasilan, (2) faktor lingkungan meliputi: penghargaan terhadap usaha yang telah dilakukan, kesempatan untuk berkembang, meningkatkan karier dan mendapatkan promosi, dukungan untuk tumbuh dan berkembang seperti pelatihan, melanjutkan pendidikan, kebijakan individual yaitu tindakan untuk mengakomodasi kebutuhan individu seperti upah atau gaji yang bisa mencukupi kebutuhan hidup. ${ }^{4}$ Penilaian atau dalam berbagai kepustakaan lazim disebut evaluasi kinerja adalah suatu metode dan proses penilaian pelaksanaan tugas seseorang atau kelompok orang atau unit-unit kerja dalam suatu perusahaan atau organisasi sesuai dengan standar kinerja. ${ }^{5}$ Kualitas kinerja perawat dapat dievaluasi secara obyektif dengan menggunakan metode dan instrumen yang baku melalui audit dokumentasi. Audit dokumentasi dilakukan dengan cara membandingkan proses dokumentasi yang ditemukan dalam rekam medis (RM) klien dengan standar pendokumentasian yang ditentukan dalam standar asuhan keperawatan. Aspek yang dinilai dalam pendokumentasian ini adalah pengkajian, diagnosis, perencanaan, tindakan, evaluasai dan catatan asuhan keperawatan.

Rumusan masalah pada penelitian ini adalah apakah ada pengaruh antara hambatan-hambatan dalam motivasi terhadap kinerja perawat di Instalasi Rawat Inap RSUD Kabupaten Buleleng? Tujuan penelitian ini adalah untuk mengetahui hambatanhambatan dalam pengembangan motivasi, kinerja, dan pengaruh hambatan-hambatan terhadap kinerja perawat.

\section{METODE}

Desain penelitian adalah kualitatif dengan pendekatan fenomenologi. Pengumpulan data primer dan sekunder dilaksanakan dari bulan Februari-Maret 2013. Data primer diperoleh dari informan yaitu kepala ruangan dan perawat pelaksana di Instalasi Rawat Inap RSUD Kabupaten Buleleng. Informan dipilih secara purposive dengan pertimbangan perbedaan job description yang mungkin menimbulkan hambatan-hambatan dalam motivasi yang berbeda sehingga mempengaruhi kinerja yang berbeda. Data sekunder diperoleh melalui studi dokumentasi pada rekam medik.

Peneliti melakukan wawancara mendalam pada perawat di nurse station menggunakan pedoman wawancara mendalam dan tape recorder dengan mengikuti asas kecukupan dan kesesuaian. Asas kecukupan tercapai jika data dari informan dapat menggambarkan fenomena yang berkaitan dengan topik penelitian, sedangkan asas kesesuaian berarti pemilihan informan sesuai dengan keterkaitan informan dengan topik penelitian. ${ }^{7}$ Sebelum wawancara mendalam informan sudah mengisi informed consent sebagai bukti persetujuan ikut dalam penelitian. Itemitem yang dikaji dalam wawancara mendalam meliputi: (1) supervisi keperawatan meliputi supervisi keperawatan saat ini, manfaat supervisi yang dirasakan perawat dan pengaruh supervisi terhadap kinerja, (2) pengembangan karir meliputi 
kondisi pengembangan karir melalui pendidikan dan pelatihan, kesempatan mengikuti pendidikan dan pelatihan, manfaat dari pengembangan karir dan pengaruh pengembangan karir terhadap kinerja perawat, (3) jasa pelayanan meliputi sistem jasa pelayanan dikaitkan dengan kompensasi berdasarkan kinerja, serta pengaruh jasa pelayanan terhadap kinerja perawat.

Studi dokumentasi rekam medik mengkaji penerapan standar asuhan keperawatan pada 60 sampel rekam medis pasien rawat inap di Ruang Cempaka, Anggrek, Sakura, Kamboja, Sandat dan Jempiring. Aspek yang dinilai terdiri dari enam komponen. Pertama, pengkajian yaitu proses keperawatan berupa pengumpulan informasi atau data klien, untuk identifikasi masalahmasalah, kebutuhan kesehatan dan keperawatan klien, baik fisik, mental, sosial dan lingkungan. ${ }^{12}$ Kedua, diagnosis keperawatan yaitu penilaian klinik mengenai respon individu, keluarga dan komunitas terhadap masalah kesehatan atau proses kehidupan yang aktual atau potensial sebagai dasar pemilihan intervensi keperawatan. ${ }^{12}$ Ketiga, perencanaan yaitu proses penentuan prioritas dan metode penyelesaian masalah kesehatan klien untuk menyusun rencana asuhan keperawatan berdasarkan respon klien terhadap masalah kesehatan aktual, risiko dan potensial. ${ }^{12}$ Keempat, implementasi, adalah kegiatan perawat untuk membantu klien menghadapi masalah status kesehatan untuk meningkatkan status yang lebih baik, yang menggambarkan kriteria hasil yang di harapkan. ${ }^{12}$ Kelima, evaluasi, adalah tindakan intelektual untuk melengkapi proses keperawatan yang menandakan keberhasilan dari diagnosis keperawatan, rencana intervensi dan implementasinya. ${ }^{11}$ Keenam, catatan asuhan keperawatan, yaitu mendokumentasikan semua kebutuhan klien, merencanakan, melaksanakan asuhan keperawatan dan mengevaluasi intervensi. Untuk mendapatkan data dokumentasi digunakan alat tulis dan buku catatan.

Metode dan teknik analisis data yang digunakan adalah secara thematic analysis, yaitu mengorganisasikan dan mengurutkan data ke dalam pola, kategori dan satu uraian dasar sehingga dapat ditemukan tema tertentu. ${ }^{6}$ Untuk menetapkan keabsahan data dilakukan teknik pemeriksaan berdasarkan derajat kepercayaan (credibility), keteralihan (transferability), ketergantungan (dependability), dan kepastian (confirmability). ${ }^{13}$ Dalam penelitian ini menggunakan teknik triangulasi. Penelitian ini mendapatkan kelaikan etik dari Komisi Etik Penelitian Fakultas Kedokteran Universitas Udayana/Rumah Sakit Umum Pusat Sanglah Denpasar.

\section{HASIL}

Hasil wawancara mendalam dengan perawat menunjukkan gambaran pengaruh supervisi keperawatan dengan kinerja perawat. Temuan pertama menunjukkan semua kepala ruangan melakukan supervisi hanya karena melaksanakan tugas dari atasan yang bersifat rutinitas, tanpa adanya monitoring dan evaluasi. Akibatnya, supervisi yang mereka lakukan berpengaruh terhadap kinerja perawat yang bersifat rutinitas juga dalam memberikan asuhan keperawatan kepada klien. Beberapa kutipan wawancara mendalam terkait temuan tersebut adalah sebagai berikut:

"Supervisi keperawatan dirasakan belum efektif dan ... kurang bermanfaat karena supervisi keperawatan yang dilakukan tidak memberikan bimbingan kepada perawat pelaksana dalam melaksanakan askep. Supervisi yang selama ini dilakukan ... hanya rutinitas saja, hal-hal yang ditanyakan seputar... : berapa jumlah pasien?, apakah sudah ada persediaan O2?, apakah ada masalah?"

“...sebagai supervisor selama ini tidak pernah dimonitoring oleh manajemen keperawatan sehingga kami sendiri sebagai supervisor tidak tahu apakah kami ini benar atau tidak dalam melaksanakan supervisi..."

“...akhirnya kinerja perawat itu tidak ada perkembangan, begitu-begitu saja hasilnya, karena kita tidak pernah memberikan bimbingan, bekerja sesuai rutinitas saja, yaaa merawat infus ...."

Temuan tersebut sejalan dengan hasil wawancara perawat pelaksana menunjukkan bahwa supervisi harian oleh supervisor hanya menanyakan hal-hal yang rutin, tidak pernah memberikan bimbingan atau dorongan kepada para perawat sehingga kinerja perawat menurun. Kutipan wawancara mendalam terkait temuan di atas adalah sebagai berikut:

"Tentu supervisi berpengaruh dengan kinerja perawat, kita terdorong untuk bekerja sesuai standar keperawatan ...namun kenyataannya supervisi disini biasa saja ...tidak berdampak pada kinerja saya ... supervisinya hanya bertanya-tanya sedikit trus pergi"

"...Cuma monoton aja yang ditanyakan seperti jumlah pasien ... tidak pernah memberikan bimbingan untuk meningkatkan kecakapan ... karena yaaa supervisinya seperti itu sehingga kinerja kita monoton, ....hanya rutinitas aja" 
Hasil wawancara mendalam yang lain terkait pengaruh pengembangan karir terhadap kinerja perawat sebagai temuan kedua. Kepala ruangan menyatakan bahwa terbatasnya sumber daya manusia (SDM) merupakan kendala dalam memberikan ijin perawat melanjutkan pendidikan karena tidak mendapatkan tenaga pengganti. Kendala yang lain adalah belum meratanya pelatihan untuk meningkatkan kompetensi yang harus dimiliki perawat di masing-masing ruang perawatan sehingga berpengaruh dengan kinerja perawat secara kualitas dan kuantitas. Berikut kutipan wawancara mendalamnya:

“...Untuk melanjutkan kuliah juga kendalanya kita kekurangan tenaga, kita di bawah memberikan ijin ... tapi dengan syarat kita tidak dikasi tenaga lagi, bagaimana caranya kita meningkatkan karir?"

"...Setiap tahun saya sudah membuat perencanaan untuk pelatihan ... tidak pernah ada realisasi ... kendalanya saya tidak tahu ...." "...setelah dia mendapatkan pelatihan itu dipindahkan ke bangsal lain jadi tidak sesuai dengan pelatihannya"

"Jadi pengaruh pengembangan karir dengan kinerja perawat itu tidak ... secara kualitas dan kuantitas tidak tercapai, .... Perawat bekerja yaaa rutinitas saja"

Hal ini juga sejalan dengan hasil wawancara pada perawat pelaksana, sebagaimana tercermin dari kutipan wawancara mendalam berikut:

“... Karena ee kalau kita tugas belajar otomatis di ruangan itu kurang tenaga, kepala ruangan jadinya tidak memberikan ijin, ...dibebankan ke kepala ruangan untuk mengatur tenaga di ruangannya"

“... Sulit untuk mengajukan ijin belajar ... karena kita kekurangan SDM ... jadinya agak sulit diberikan ijin ... trus untuk pelatihannya sangat minim sekali ... di ruangan saya sama sekali tidak tersentuh pelatihan " ... jadinya kinerja perawat itu cuman menjadi rutinitas seperti biasa, merawat pasien, menyuntik, tidak ada kemajuanlah dalam kinerjanya"

Temuan yang ketiga terkait pengaruh jasa pelayanan dengan kinerja perawat dimana semua kepala ruangan dan semua perawat pelaksana mengatakan bahwa jasa pelayanan yang diterima tidak sesuai dengan harapan atau tindakan yang telah mereka lakukan kepada klien, sehingga berpengaruh dengan kinerja perawat yang mereka katakan sebagai kerja rutinitas. Berikut kutipan wawancara mendalam:
“... Kita sudah bekerja, pasien membludak, kerja banting tulang tapi kenyataannya jasanya tidak sesuai dengan kerja kita ...jasanya segitusegitu aja kadang turun lagi,..."

“... Jasa pelayanan menurun sehingga kinerja teman-teman di sini menurun, ... yaa kerja kita agak ngekohan bedik,... bukan menambah kinerja tapi mengurangi kinerja sehingga kinerja perawat menjadi monoton, tidak maksimal atau tidak professional"

“... Apabila jasa pelayanannya kurang, kinerja kita semakin menurun karena motivasi dari itu tidak ada, ... kalau jasanya turun, kerjanya jadi ogah-ogahan, rutinitas aja yang bisa kita lakukan, yaa tidak maksimallah kita dalam melakukan pekerjaan"

"Tentunya jasa pelayanan berpengaruh dengan kinerja kita, tapi jasa pelayanan yang saya terima tidak sesuai dengan harapan saya ... kita bekerja lagi-lagi rutinitas"

Hasil studi dokumentasi rekam medik menunjukkan bahwa perawat belum melakukan kinerja dengan baik. Hal tersebut terlihat dari capaian yang tidak maksimal dalam 6 hal yang dievaluasi. Dalam aspek pengkajian, perawat tidak melakukan kajian sejak pasien masuk hingga pulang. Sedangkan dalam aspek diagnosis, sebagian perawat belum merumuskan diagnosis sesuai masalah dan sejalan dengan PE/KEP. Dalam hal perencanaan, tindakan, evaluasi serta asuhan keperawatan, cukup banyak item-item yang belum memenuhi standar asuhan keperawatan sebagaimana tersaji dalam Tabel 1.

\section{DISKUSI}

Hasil penelitian menunjukkan bahwa supervisor tidak memberikan dorongan, bimbingan dan kesempatan bagi pertumbuhan dan perkembangan keahlian dan kecakapan para perawat sehingga berpengaruh dengan kinerja perawat dimana hasil kerja perawat yang dapat dicapai secara kualitas dan kuantitas tidak sesuai dengan tanggungjawab yang diberikan kepadanya. Perawat yang tugas pokoknya melaksanakan asuhan keperawatan dituntut untuk meningkatkan kinerjanya, hal ini dapat ditentukan dari kesetiaan dan komitmen yang tinggi pada pencapaian hasil pelaksanaan tindakan asuhan keperawatan sesuai standar asuhan keperawatan yang berlaku, yang juga dipengaruhi oleh adanya supervisi keperawatan terhadap kegiatan asuhan keperawatan oleh perawat di ruang rawat inap. ${ }^{8}$ Hasil penelitian ini sesuai dengan penelitian yang dilakukan oleh Lupiah, ${ }^{8}$ di RSUD Kefamenanu di dapatkan bahwa ada hubungan yang signifikan antara supervisi dengan kinerja perawat dalam 
Tabel 1 Hasil studi dokumentasi penerapan standar asuhan keperawatan di Ruang Cempaka, Anggrek, Sakura, Sandat, Kamboja, Jempiring, RSUD Kabupaten Buleleng

\begin{tabular}{|c|c|c|}
\hline Aspek yang dinilai & Ya (\%) & Tidak (\%) \\
\hline \multicolumn{3}{|l|}{ Pengkajian } \\
\hline Mendokumentasikan data sesuai pedoman & $60(100)$ & - \\
\hline Data dikelompokkan (bio-psiko-sosio-spiritual) & $60(100)$ & - \\
\hline Data dikaji sejak klien masuk sampai pulang & - & $60(100)$ \\
\hline $\begin{array}{l}\text { Masalah dirumuskan berdasarkan kesenjangan status kesehatan dengan norma dan pola fungsi } \\
\text { kehidupan }\end{array}$ & $60(100)$ & - \\
\hline \multicolumn{3}{|l|}{ Diagnosis } \\
\hline Diagnosis berdasarkan masalah yang telah dirumuskan & $41(68)$ & $19(32)$ \\
\hline Diagnosis keperawatan mencerminkan PE/PES & $51(85)$ & $9(15)$ \\
\hline Merumuskan diagnosis keperawatan aktual/potensial & $60(100)$ & - \\
\hline \multicolumn{3}{|l|}{ Perencanaan } \\
\hline Berdasarkan diagnosis keperawatan & $56(93)$ & $4(7)$ \\
\hline Disusun menurut urutan prioritas & $14(23)$ & $46(77)$ \\
\hline Rumusan tujuan mengandung komponen perubahan, perilaku, kondisi klien dan/kriteria & $37(62)$ & $23(38)$ \\
\hline Rencana intervensi mengacu tujuan dengan kalimat perintah, terinci dan jelas, melibatkan klien/keluarga & $23(38)$ & $37(62)$ \\
\hline Rencana intervensi menggambarkan keterlibatan klien/keluarga & $4(7)$ & $56(93)$ \\
\hline Rencana intervensi menggambarkan kerjasama dengan tim kesehatan lain & $59(98)$ & $1(2)$ \\
\hline \multicolumn{3}{|l|}{ Intervensi } \\
\hline Intervensi dilaksanakan mengacu pada rencana asuhan keperawatan & $5(8)$ & $55(92)$ \\
\hline Perawat mengobservasi respons klien terhadap intervensi keperawatan & $1(2)$ & $59(98)$ \\
\hline Revisi intervensi berdasarkan hasil evaluasi & - & $60(100)$ \\
\hline Semua intervensi yang telah dilaksanakan di dokumentasikan dengan ringkas dan jelas & $3(5)$ & $57(95)$ \\
\hline \multicolumn{3}{|l|}{ Evaluasi } \\
\hline Evaluasi mengacu pada tujuan & - & $60(100)$ \\
\hline Hasil evaluasi didokumentasikan & $60(100)$ & - \\
\hline \multicolumn{3}{|l|}{ Catatan asuhan keperawatan } \\
\hline Menulis pada format yang baku & $60(100)$ & - \\
\hline Pendokumentasian sesuai dengan intervensi yang dilaksanakan & $59(98)$ & $1(2)$ \\
\hline Pendokumentasian ditulis dengan jelas, ringkas istilah yang baku dan benar & $1(2)$ & $59(98)$ \\
\hline $\begin{array}{l}\text { Setiap melakukan intervensi/kegiatan perawat mencantumkan paraf dan nama dengan jelas serta tanggal } \\
\text { dan jam dilakukannya intervensi }\end{array}$ & $59(98)$ & $1(2)$ \\
\hline Berkas catatan keperawatan disimpan sesuai dengan ketentuan yang berlaku & $60(100)$ & - \\
\hline
\end{tabular}

melaksanakan asuhan keperawatan. Hal ini juga sejalan dengan Teori Dua Faktor dari Hezberg yaitu faktor ekstrinsik bahwa supervisi atau pengawasan berkualitas merupakan salah satu faktor motivasi yang mempengaruhi kinerja. ${ }^{9}$

Hasil penelitian menunjukkan bahwa pengembangan karir melalui pendidikan dan pelatihan terkendala terbatasnya sumber daya manusia sehingga mempengaruhi kinerja perawat yang tidak profesional. Hasil penelitian ini sejalan dengan penelitian yang dilakukan oleh Yosephus, ${ }^{10}$ di Ruang Instalasi Gawat Darurat di salah satu RS di Kupang yaitu pengembangan karir perawat juga mengalami masalah peningkatan pendidikan ke jenjang yang lebih tinggi dan pelatihan perawat yang kurang diperhatikan oleh pihak manajemen. Perhatian yang kurang dari pihak RS terhadap upaya pengembangan karir perawat dalam rangka peningkatan mutu pelayanan juga menjadikan perawat enggan untuk meningkatkan kinerjanya dan cenderung melakukan aktivitas yang rutin saja. Pendidikan dan pelatihan membantu perawat dalam mengembangkan berbagai ketrampilan tertentu untuk keberhasilan asuhan keperawatan yang diberikan kepada klien saat ini dan mengembangkan pekerjaannya di masa mendatang sehingga akan meningkatkan kinerjanya. $^{10}$ 
Penelitian juga menunjukkan bahwa jasa pelayanan yang diterima tidak sesuai dengan harapan perawat sehingga berpengaruh terhadap kinerja perawat yang menurun. Sistem pemberian jasa pelayanan yang dipergunakan RS dalam memberikan imbalan dapat mempengaruhi motivasi kerja perawat. Kesalahan dalam menerapkan sistem pemberian jasa pelayanan akan berakibat timbulnya demotivasi dan hal tersebut dapat menyebabkan turunnya kinerja serta akan berdampak pada menurunnya kinerja RS. ${ }^{2}$

Studi dokumentasi pada aspek pengkajian, menunjukkan kajian hanya dilakukan pada awal masuk rumah sakit dan tidak pernah melakukan pengkajian lanjutan sampai klien pulang. Akibatnya, diagnosis keperawatan pada saat klien dirawat sampai pulang tetap sama atau apabila ada masalah keperawatan baru, maka tidak ada diagnosis keperawatan baru yang didokumentasikan. Pengumpulan data seharusnya dimulai sejak klien masuk RS (initial assessment), selama klien dirawat (ongoing assessment), serta pengkajian ulang (re-assessment). ${ }^{12}$ Diagnosis keperawatan tidak sesuai dengan rumusan masalah saat pengkajian awal. Contohnya, dalam pengkajian disebutkan masalah gangguan sistem respirasi, tetapi diagnosis keperawatannya gangguan rasa nyaman. Selain itu, pendokumentasian diagnosis keperawatan tidak sesuai dengan penerapan standar asuhan keperawatan, sehingga perawat akan mengalami kesulitan menentukan intervensi keperawatan klien. ${ }^{12}$ Perencanaan intervensi keperawatan yang tidak sesuai dengan standar asuhan keperawatan dapat menimbulkan hambatan proses evaluasi keberhasilan asuhan keperawatan. ${ }^{11}$ Dokumentasi implementasi keperawatan yang tidak sesuai dengan penerapan standar mencerminkan kurangnya ketrampilan intelektual, interpersonal dan teknis yang diperlukan untuk implementasi rencana keperawatan.

Evaluasi keperawatan yang didokumentasikan perawat berdasarkan rutinitas tindakan keperawatan yang telah diberikan kepada klien sehingga tidak mengacu pada standar dan berpotensi menyebabkan tujuan dari evaluasi tersebut tidak tercapai. ${ }^{12}$ Kegagalan membuat catatan yang benar dapat dianggap kelalaian dan menjadi dasar liabilitas yang merugikan. Pengkajian dan dokumentasi yang tidak memadai atau tidak akurat dapat menghalangi diagnosis dan terapi yang tepat dan mengakibatkan cedera pada klien..$^{12}$ Audit dokumentasi adalah cara untuk mengetahui tingkat keberhasilan asuhan keperawatan, menggunakan metode dan instrumen penilaian yang baku dengan membandingkan pendokumentasian yang ditemukan dalam rekam medis klien dengan standar. Melalui studi ini, kinerja perawat terlihat sebagai hasil kerja yang bersifat rutinitas tanpa adanya penerapan standar yang baku serta tanpa adanya monitoring dan evaluasi.

\section{SIMPULAN}

Supervisi keperawatan oleh kepala ruangan terkait dengan kinerja perawat hanya bersifat rutinitas, pengembangan karir terkait dengan kinerja perawat yang kurang profesional dalam memberikan asuhan keperawatan kepada klien, jasa pelayanan yang tidak sesuai harapan terkait dengan kinerja perawat yang menurun. Dokumentasi asuhan keperawatan tidak sesuai dengan pedoman penerapan standar asuhan keperawatan di RS terkait dengan kinerja perawat.

\section{UCAPAN TERIMA KASIH}

Ucapan terimakasih penulis sampaikan kepada Direktur RSUD Kabupaten Buleleng yang telah memberikan ijin penelitian, serta semua rekan yang telah membantu terselesainya pelaksanaan penelitian ini.

\section{DAFTAR PUSTAKA}

1. RSUD Kabupaten Buleleng. Laporan Tahunan Tahun 2011. Buleleng; 2012.

2. Wibowo. Manajemen Kinerja. Jakarta: PT Raja Grafindo Persada; 2012.

3. Winardi J. Motivasi dan Pemotivasian dalam Manajemen. Jakarta: PT Raja Grafindo; 2012.

4. Suarli S, Bahtiar Y. Manajemen Keperawatan dengan Pendekatan Praktis. Jakarta: Penerbit Erlangga; 2012.

5. Sinambela LP. Kinerja Pegawai: Teori Pengukuran dan Implikasi. Yogyakarta: Graha Ilmu; 2012.

6. Moleong LJ. Metode Penelitian Kualitatif. Bandung: PT Remaja Rosdakarya; 2007.

7. Nahrisah P. Evaluasi Pelaksanaan Program Terapi Rumatan Metadon di Puskesmas Kecamatan Tanjung Priok Tahun 2008 [skripsi]. Jakarta: Universitas Indonesia; 2008.

8. Lupiah L. Hubungan Faktor-faktor Motivasi dengan Kinerja Perawat dalam Melaksanakan Asuhan Keperawatan di Ruang Rawat Inap Rumah Sakit Umum Daerah Kefamenanu Kabupaten TTU [skripsi]. Kupang: Universitas Cendana; 2009.

9. Ilyas Y. Kinerja: Teori, Penilaian dan Penelitian. Jakarta: Pusat Kajian Ekonomi Kesehatan FKM-UI; 2002.

10. Yosephus A. Motivasi Kerja dan Pengembangan Karir Perawat di Ruang Instalasi Gawat Darurat Prof. Dr. W.Z. Johannes Kupang [skripsi]. Semarang: Universitas Diponegoro; 2011.

11. Nursalam. Proses dan Dokumentasi Keperawatan-Konsep dan Praktik. Jakarta: Salemba Medika; 2009.

12. Dermawan D. Proses Keperawatan: Penerapan Konsep dan Kerangka Kerja. Yogyakarta: Gosyen Publishing; 2012.

13. Sugiyono. Metode Penelitian Kuantitatif, Kualitatif, dan R \& D. Bandung: Alfabeta; 2012.

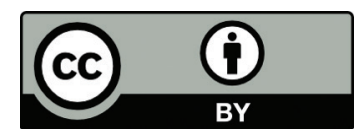

This work is licensed under a Creative Commons Attribution 